Yusuke Nakamura, who directs a large SNPs project at Tokyo University's Institute of Medical Science. "But it is unclear how to ensure the rights of patients, and how to deal with patients whose privacy has been violated, and who may be subject to various forms of genetic discrimination."

Nakamura says that many patients are afraid to provide samples, following speculation that genetics research could lead to social discrimination. "Legal regulation, including penalties for those who do not comply, should be established as soon as possible," he says.

Some observers fear that insufficient regulation could provoke further media criticism, making it harder to obtain human samples. The supply of these is hindered by a lack of links between scientists and clinicians.

"Much recent trouble concerning human samples has been caused by a lack of communication between medical doctors and researchers," says Yoshihide Hayashizaki, who leads the Genome Exploration Research Group at RIKEN's Genomic Sciences Center.

Nobuyoshi Shimizu, who directs the Center for Genomic Medicine at the Keio University School of Medicine, says that it is "difficult to obtain fresh tissue samples". He argues that national facilities are needed to prevent the commercialization of the supply of human tissue samples.

Guidelines for the use of human cells and tissues were published last year by an ethics panel at the Japan Tissue Culture Association, headed by Toshiharu Matsumura, a general manager at the Meiji Cell Technology Center. Matsumura sees them as a "first step" towards a regulatory framework. Robert Triendl

\section{Gene therapy institute denies that errors led to trial death}

Washington

The director of the gene therapy institute where a patient died during treatment last September has admitted errors in the administration of its trials, but denies that they led to the patient's death.

The US Food and Drug Administration (FDA) recently shut down five clinical trials at the University of Pennsylvania's Institute of Human Gene Therapy (IHGT) after an investigation found 18 possible violations in the way the institute had run and monitored an earlier trial (see Nature 403, 354; 2000).

In a letter to the FDA, James Wilson, director of the institute, acknowledges errors in the trial - the first in which a death has been attributed directly to the experimental treatment (see Nature 401, 517; 1999).

Wilson does not not accept all 18 of the FDA's preliminary findings, but he admits perhaps the most serious charge: that the institute failed to contact the FDA when two patients who received an adenoviral vector with a therapeutic gene for a liver-enzyme deficiency experienced adverse effects.

Under the protocol, the IHGT should have notified the FDA immediately. Wilson says that the institute had reported similar effects in two previous patients, and that the FDA had allowed the trial to resume in both cases. He points out that the FDA received written records of those adverse effects before permitting the IHGT to use higher doses on other patients, but wrote that "IHGT should not have proceeded as it did".

But Wilson denies several other serious charges. For example, he says that Jesse Gelsinger, the Arizona man who died in the

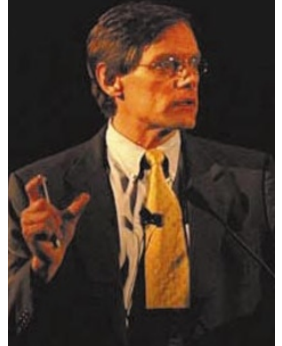

Wilson: admits that procedures were lax. experiment, was eligible for treatment despite having a high level of ammonia before the treatment. The protocol specified only that the enzyme level should be normal at the time of enrolment, not treatment, and it is "common" for such enzyme levels to fluctuate, Wilson says in his letter.

Also, he says that the researchers did not inform Gelsinger of the deaths of two primates because they were models for a different disease and received a different therapeutic gene.

Finally, the university report contradicts Paul Gelsinger, Jesse's father, who, at a recent Senate hearing, said that investigators did not follow procedures for informed consent properly (see Nature 403, 583; 2000). "Each and every patient in the ... trial gave clear and unambiguous consent to participate."

Wilson declined to comment further. But Kenneth Wildes, a university spokesman, says: "We made some mistakes, but those mistakes did not lead to the death of Jesse Gelsinger." Wildes adds: "We're not minimizing the conduct of researchers at Penn. They should be held to the highest standards."

Wilson says in his letter that, if allowed to resume its suspended trials, IHGT would be willing to be more closely monitored, and to follow more stringent reporting requirements.

Paul Smaglik

\title{
US physics society puts feisty newsletter in doubt
}

\section{Washington}

What's New, a popular and often scurrilous weekly news summary read by more than 10,000 physicists and followers of science policy in the United States and abroad, could cease publication in July, following the American Physical Society's (APS) threat to stop supporting its author, Bob Park.

The APS wrote last month to the physics department at the University of Maryland at College Park, where Park is a professor, saying that it wants to cut its support from twothirds to one-half of his salary.

If that happens, says Park, he will have to increase his teaching and other commitments at the university, and will be unable to continue his work for the APS, which includes the production of What's New. Given the lack of effort involved, he describes the APS letter as "an adiabatic firing".

Park has served as a kind of freelance mouthpiece for the APS for many years. He writes frequent columns for The New York Times and other newspapers on everything from global warming to the recent spying scandal at nuclear weapons laboratories.

Neither the columns nor the What's New electronic newsletter are attributed directly to the APS - the newsletter always ends with Park's signature line: "Opinions are the author's and are not necessarily shared by the APS, but they should be." But they do reflect the views of many physicists, and give the community a rapid response to current events
— lacking in most scientific societies, which can take months to agree a point of view.

As news of the APS plan leaked out during the meeting of the American Association for the Advancement of Science in Washington last week, some physicists were planning to write to the new APS president, Jim Langer, of the University of California at Santa Barbara, to protest at the decision. Some suggest that Park may have offended someone once too often.

Jerome Friedman of the Massachussetts Institute of Technology, last year's APS president, said that he didn't want to discuss the matter "until it was resolved". But he added: "There is no dissatisfaction with Bob — it's a question of resources."

Colin Macilwain 